\title{
THE ROLE OF DEMOGRAPHIC FACTORS IN CONSUMER PERCEPTION OF VALUE FROM BRAND COMMUNICATION ON FACEBOOK
}

Klepek, M.

Martin Klepek / Silesian University, School of Business Administration in Karvina, Department of Business Economics and Management, Univerzitní náměstí 1934/3, Karviná, Czech Republic. Email: klepek@opf.slu.cz.

\begin{abstract}
With a growing interest in social media, social networks have been discussed largely in brand management and marketing communications literature. Specifically, Facebook, as the leading brand in social networks, is increasingly popular both for users and companies. However, it is not entirely clear what differences occur among Facebook users regarding their attitudes toward brand profiles. The goal of the research is to identify which demographic factors are related to the functional and hedonistic attitude towards the brand fan page and the overall social value of the page on Facebook. A quantitative survey was conducted on a representative sample of 454 users. The concepts of functional, hedonic and social value were measured using Likert-type questions (four for each of these concepts). Using cluster analysis, homogeneous groups were identified in the data set, resulting in two main segments for the functional and hedonic concept and three for social value. Subsequently, these groups were compared with selected demographic characteristics using Chi-square statistics.

Implications for Central European audience: Results of the analysis showed that there is no evidence that gender or age relates to any attitudinal measures towards brand pages on Facebook. The paper ends with a conclusion about the usability of the results for further research and business practice.
\end{abstract}

Keywords: brand; Facebook; marketing communications; social media; social networks; value

JEL Classification: M31

\section{Introduction}

Social media are today's global phenomena. Even the most mundane routines in the early morning have been replaced by switching on technological devices and logging on is now first thing in the morning for many, even before getting up (Llamas \& Belk, 2018). These new platforms dominate communication between Internet users surpassing email, Internet telephony, VolP, Internet Relay Chats or SMS. It changes the way people connect with each other, both in the type of interactions that take place and in the quantity and quality of information that is available (Hoffman, Novak \& Stein, 2012). Thus, it became a must-have tool for almost everyone responsible for marketing communication in business. The most 
popular social media type are social networking sites. These platforms provide a link to users who create content that other people interact with. In this new environment, it is important for marketers to be able to manage marketing communications effectively.

Facebook has the strongest position in the social networking market. It is used by more than two billion people around the world every month (Hutchinson, 2019). This platform is popular among both men and women, and in terms of age, the segment of the thirties has been expanding recently (Clement, 2019). Thus, a marketer can communicate with almost all types of consumer groups and segments. Interestingly, the availability of internet connection in particular countries and regions has a greater influence on Facebook usage than the age of consumer groups.

We already know that almost all demographic can be reached through Facebook. But concerning the motivation to follow brands and establish the connection on this platform, the question is, what value does the brands Facebook profiles deliver to the Facebook users? What is the motivation to follow the brand and how these factors are reflected in user demographics? Is there any key to split the consumers into groups and approach them differently by using age or gender segmentation criteria? If we were able to create a typology that would link demographics and values, it would be much easier to understand the phenomenon and consequently to manage brands profiles more effectively.

\section{Conceptual framework}

The theoretical grounding of this paper touches on several concepts. From a general marketing perspective, it is Social media and Social networks as two interconnected terms. The first one is a group of Internet-based applications that build on the ideological and technological foundations of Web 2.0, and that allow the creation and exchange of User Generated Content (Kaplan \& Haenlein, 2010). The second is the more specified type of social media platform build on interconnections. Social networks are defined in today's media space as online systems of user groups that can create and maintain contact, generate content, and share this content with other users (friends, acquaintances, co-workers). Boyd \& Ellison (2007) describe them as a service that allows a person to (1) create a public or semi-public profile within the bounded system, (2) select a list of other users with whom they can share the link, and (3) see and browse the list of your connections and a list of other users' connections within the system. These sites allow users to publish and interchange opinions and experiences about brands and their products and services (Sabate et al., 2014). In the Czech Republic, the majority of heavy internet users had profiles on several social networking sites (Tomek et al., 2012).

Social networking sites offer brands several options to contact and communicate with their customers, but in general, the options vary across platforms. What differentiates Facebook from other social networks is the way in which it welcomes business, opening platform to users through applications, penetrating websites via social plug-ins and transforming itself into a privileged marketing channel enhanced with social ads (Pereira et al., 2014). Brands are allowed to join these social networks and play an equal role to usual members in content creation, communication, interactions and information acquisition. This communication paradigm shift is largely described in the literature (Hoffman \& Novak, 1996; Duncan \& Moriarty, 1998; Kiani, 1998; Ozuem et al., 2008; Killian \& McManus, 2015). 
More than a few studies confirmed the positive effect of Facebook on marketing performance. Specifically, the positive effect has been documented on brand image and brand equity (Greve, 2014; Dehghani \& Tumer, 2015), purchase intentions (Duffett, 2015) and ecommerce sales (Brettel et al., 2015). These results can be achieved in two general ways. First, Facebook advertising system provides a platform for ads which can be tailored to specific target users. Second, messages can be created within a brand fan pages. These are brand oriented profiles that provide additional functionalities like detailed analytics and better content and fans administration (Sabate et al., 2014). On these brand fan pages, companies can create brand posts containing anecdotes, photos, videos, or other material; brand fans can then interact with these brand posts by liking or commenting on them (De Vries et al., 2012).

Interactions like this are commonly described as customer engagement. Van Doorn et al. (2010) describe it as behaviour which goes beyond transactions and may be specifically defined as a customer's behavioural manifestations that have a brand or firm focus, beyond purchase, resulting from motivational drivers. Alternatively, Brodie et al. (2011) define consumer engagement as a psychological state that occurs by virtue of interactive, cocreative experiences with a brand in a focal service relationship. Nevertheless, consumer engagement with a Facebook fan page has positive effects on consumers' brand awareness, brand equity, WOM activities, purchase intention, corporate reputation, trust and brand evaluation (Hutter et al., 2013; So et al., 2014; Schivinski \& Dabrowski, 2015; Schivinski \& Dabrowski, 2016; Dijkmans et al., 2015; Novotná, 2018).

The question is then what motivates consumers to follow brands and exhibit consumer engagement. This motivation can be explained by the concept of value which is central to marketing theory. Also, social psychology and communication literature have attempted to explain media consumption in general by assuming consumers are active agents who make purposeful decisions to gratify their individual needs with media (Larivière et al., 2013). People use media to satisfy various needs and to achieve their goals, and the most prominent needs can be subsumed into three areas: A content-oriented area based on the information delivered by the media, a relationship-oriented area based on social interaction with others, and a self-oriented area based on particular needs of individuals such as achieving status or need for diversion (Jahn \& Kunz, 2012). Consequently, the aforementioned gratification principles can be translated into three types of value which are embedded in brand fan page usage. For instance, Abdul-Ghani et al. (2011) used utilitarian, hedonic and social benefits. Similarly, De Vries \& Carlson (2014) used functional, hedonic and social values. This paper uses later terminology to describe the dimensions of brand fan pages value.

The first value is functional and refers to information acquisition behaviour. Customer's goal is to get information about the brand, its products, provided services, prices or any other type of functional value in the form of the information on its fan page. It is also a sales promotion which motivates users to become a fan of the page and get the latest information about promotion campaigns instantly. Further, the website is very often the aggregator of valuable sources for buying decision. The customer can seek advice or reduce risk during the decisionmaking process (Muntinga et al., 2011). Additionally, functional experiences have long been documented in the literature on technology acceptance (Davies, 2011) and provide an important rationale for content creation on the social network. 
Moreover, the motivation to use an information system such as the social network site could also be grounded in hedonic value. It refers to the perceived enjoyment, excitement or stimulation that customers experience by engaging with a brand fan page (Carlson et al. 2018). Perceived enjoyment is an important factor in predicting the intention to use a pleasure-oriented information system (Van der Heijden, 2004). According to Lin and Lu (2011) and their research, which showed a significant effect of enjoyment on social network usage, entertainment is a non-disturbing way of getting attention. Additionally, the high perceived hedonic value of the brand fan page triggers the customer to use the brand page more frequently (De Vries \& Carlson, 2014). Entertaining content is one of the main drivers for fan page participation and usage (Cvijikj \& Michahelles, 2013).

We should point out here, that communication with a brand is not the single neither the main reason to visit a social network. People visit these websites to communicate with friends and family and to share the information about their lives with their peers (Bonds-Raacke \& Raacke, 2008; Hennig-Thurau et al., 2010; Karlíček et al., 2012; Lee et al., 2014; Logan, 2014; Scheinbaum, 2018; Sheldon, 2008). The social value associated with interactions with other fans on the brand fan page has huge implications for marketers. This is also illustrated by previous research. Daugherty et al. (2008) discovered that the motivation to form online content is the most affected by the interest in social interaction. Social and community value has also been proven to be the relevant antecedent of engagement in a study by Dessart et al. (2015). Moreover, Wang \& Chang (2013) contributed to the topic by their study of how the product information and recommendations provided by friends on Facebook with whom consumers have strong ties increases the probability that the consumers will purchase the product in question. Also, Flóres et al. (2018) concluded that people are open to receive the opinions of their peers (friends, acquaintances or other consumers) to make purchasing decisions. Despite the fact that we often see the community as something that emerges spontaneously, companies can make their own online community, proactively manage them, or just use data from these online social communities for their own customer relationship management system (Bachman \& Kantorová, 2016).

If we take into consideration the fact that men's and women's shopping behaviour differs on many levels (Coley \& Burgess, 2003), it would be interesting to see if they also differ in the perceived functional, hedonic and social value of following brands on social networks. Research showed significant differences in information processing (Barber, 2009) thus, the functional benefit of the following brand and get the latest information about products could vary across gender. Likewise, some studies discovered differences in hedonic shopping behaviour between men and women (Tifferet \& Herstein, 2012; Yang \& Lee 2010). Finally, gender is also a differentiator in social interaction and social network usage (Kimbrought et al., 2013; Muscanell \& Guadagno, 2012). Another demographic criterion regularly used to segment the market is age. Similarly to gender, there are studies showing differences in social media usage and in particular variances in social network behaviour (Duffett, 2017; Bolton et al. 2013; Brooks \& Anene, 2012). Exploring the influence of age on brand profile value perception will provide new insight into Facebook fans segmentation.

In summary, the theoretical framework of this study is formed by the functional, hedonic and social value of the brand fan page on Facebook which has been previously discussed in the literature (Jahn \& Kunz, 2012; De Vries \& Carlson, 2014). Two demographic, age and gender, are additional variables which could help to understand the Facebook user's perception 
better. Therefore, the research question is: Does these three elementary types of values displayed in the brand fan page on Facebook differs across the gender or age categories?

\section{Research methodology}

To answer the research question, it was necessary to use a predominantly deductive approach to testing a predefined theoretical framework. The nature of the method was quantitative, and the research strategy was the survey method. The technique of data collection was an online questionnaire which was sent to 840 respondents from the Czech internet population. It was distributed in cooperation with the professional research agency IPSOS through its online respondent panel. The panel is certified by SIMAR authority and has several control mechanisms to ensure data quality. There is a respondent's duplicity control, limits for the maximal participation of each respondent in studies, respond time check or identity and personal data validation. There was one limitation for respondents to enter the study. Only those who stated their favourite brand on the social network Facebook were allowed to proceed.

The agency provided raw data with no standardization, and despite the mentioned mechanisms for quality control, we examined the data set for a few standard problems. Based on the recommendation of Hair et al. (2017) the data were subjected to the analysis of suspicious response patterns. The elementary problem is straight-lining when respondent marks the same response for all or for a high proportion of the questions. We used the standard deviation of battery method, which simply calculates the standard deviation (or variance) of the rating scale for each respondent (Kim et al., 2019). Higher scores indicate less straight-lining, and thus, it is a measure of variation. For the purpose of the study, the high scores were set as ten straight linings out of 12 scale questions offered. By measuring the standard deviation, those suspicious patterns were easily identified in the data file. Respondents with a null standard deviation (64) and those who filled in more than 9 cases the same ratings (322) were eliminated from the sample for further statistical processing. Further, analysis of blank cells in Microsoft Excel showed complete data from all 840 respondents. Visual control methods were used to test the normality of data (Blunch, 2013). All variables were slightly positively skewed with few negative kurtosis ones, but overall the histograms did not show any major normality problems. In conclusion, 54\% (454) of the original respondents were kept in the sample.

The minimal sample size was based on a statistical approach which is, in comparison with cost approach or blind estimation, more rigorous. With a confidence interval of $95 \%$, the reliability estimate is 1.96 , and the allowable margin of error estimate \pm 5 and the minimum sample size is 384 respondents (Saunders et al., 2009). Thus, the final sample exceeded the minimum sample requirements by $18 \%$. Specifically, $54.4 \%$ were males and $45.6 \%$ females from all 14 regions of the Czech Republic (Table 1). There were all age groups ranging from 18 years of age to 65 with the mean of 39 years and a standard deviation of 12.67. Majority of respondents $(70.3 \%)$ had a high school education, but $28.4 \%$ had only the certificate of apprenticeship. Thirty-seven respondents have undergone just elementary school education. Compared to the internet population (SPIR, 2019), there are some minor disproportions. First, there is $4.4 \%$ more man in the sample than in the internet population. The educational level also differs; however, there is a maximal deviation in the number of high school respondents which is $5.9 \%$. Overall deviation in this strata criterion is $3.25 \%$ on average. Further, the sample represents very precisely also the age characteristics of the population. The strongest 
deviation is between $55+$ generation, where the difference is $8.5 \%$ comparing sample and population. Combined into average, the overall deviation in the age category is $3.4 \%$. Though there is no perfect match, the sample size and structure of the particular strata shows it is fairly representative.

Table 1 | Research sample description and internet population comparison

\begin{tabular}{|c|c|c|c|}
\hline \multirow{2}{*}{$\begin{array}{l}\text { Characteristics } \\
\mathrm{n}=454\end{array}$} & \multicolumn{2}{|c|}{$\begin{array}{c}\text { Research } \\
\text { sample }\end{array}$} & \multirow{2}{*}{$\begin{array}{c}\begin{array}{c}\text { Internet } \\
\text { population }\end{array} \\
\text { Population (\%) } \\
\end{array}$} \\
\hline & Frequency & Sample (\%) & \\
\hline \multicolumn{4}{|l|}{ Gender } \\
\hline Female & 207 & 45.6 & 50 \\
\hline Male & 247 & 54.4 & 50 \\
\hline \multicolumn{4}{|l|}{ Education } \\
\hline Elementary school & 37 & 8.1 & 7 \\
\hline Certificate of apprenticeship & 129 & 28.4 & 31 \\
\hline High school & 190 & 41.9 & 36 \\
\hline University & 98 & 21.6 & 25 \\
\hline \multicolumn{4}{|l|}{ Age } \\
\hline $15-24$ & 70 & 15.4 & 15 \\
\hline $25-34$ & 108 & 23.8 & 20 \\
\hline $35-44$ & 113 & 24.9 & 24 \\
\hline $45-54$ & 94 & 20.7 & 17 \\
\hline $55+$ & 69 & 15.2 & 24 \\
\hline \multicolumn{4}{|l|}{ City } \\
\hline Up to 1000 inhabitants & 85 & 18.7 & Not provided \\
\hline 1001 to 5000 inhabitants & 82 & 18.1 & Not provided \\
\hline 5001 to 20000 inhabitants & 73 & 16.1 & Not provided \\
\hline 20001 to 100000 inhabitants & 99 & 21.8 & Not provided \\
\hline More than 100000 inhabitants & 115 & 25.3 & Not provided \\
\hline
\end{tabular}

Source: author

Respondents were asked within the first question to fill the name of their favourite brand fan page on Facebook. This process ensured they related the answers to particular questions to a specific brand. Further, based on the established scales from previous research (Jahn \& Kunz, 2012; De Vries \& Carlson, 2014) the questionnaire was designed to measure the latent variables: Functional value (FUNCVAL), Hedonic value (HEDONIC) and Social value (SOCVAL) of the fan page. For each latent construct, there were four-item questions asked (Tab. 2). All items in the form of twelve statements were evaluated by respondents on six points Likert scale ranging from completely agree to completely disagree. 
Table 2 | Constructs and items in questionnaire

\section{Construct (CODE) No. Item statement}

\begin{tabular}{|c|c|c|}
\hline \multirow{4}{*}{$\begin{array}{l}\text { Functional value } \\
\text { (FUNCVAL) }\end{array}$} & 1 & The content of the fan page is helpful for me. \\
\hline & 2 & The content of the fan page is functional for me. \\
\hline & 3 & The content of the fan page is practical for me. \\
\hline & 4 & The brand offers important information on its fan page. \\
\hline \multirow{4}{*}{$\begin{array}{l}\text { Hedonic value } \\
\text { (HEDONIC) }\end{array}$} & 1 & The content of the fan page is fun. \\
\hline & 2 & The content of the fan page is pleasant. \\
\hline & 3 & The content of the fan page is entertaining. \\
\hline & 4 & The content of the fan page is exciting. \\
\hline \multirow{4}{*}{$\begin{array}{l}\text { Social value } \\
\text { (SOCVAL) }\end{array}$} & 1 & I can meet people like me on this fan page. \\
\hline & 2 & I can find out about people like me on this fan page. \\
\hline & 3 & I can interact with people like me on this fan page. \\
\hline & 4 & I enjoy conversation with other fans of my favourite brand. \\
\hline
\end{tabular}

Source: author's elaboration based on Jahn \& Kunz (2012) and De Vries \& Carlson (2014)

Reliability test in the form of internal consistency for each factor using Cronbach's Alfa was performed in IBM SPSS Statistics 21 (Tab.3). All three latent factors showed decent internal consistency values.

Table 3 | Reliability test for latent factors

\begin{tabular}{llll}
\hline Construct & Code & Number of questions & Cronbach's Alfa \\
\hline Functional value & FUNCVAL & 4 & 0.853 \\
\hline Hedonic value & HEDONIC & 4 & 0.737 \\
\hline Social value & SOCVAL & 4 & 0.852
\end{tabular}

Source: author

After the initial data screening and reliability check, the further statistical operations were performed to classify the respondents and to measure relations between created classes and observed demographics data. The series of cluster analysis was used to generate a typology of social network users based on the type of value they get from a fan page. The technique is used to group the cases into homogenous sub-groups based on responses to variable or variables. First cluster analysis was performed on functional value variables (4 items). SPSS TwoStep Cluster Component was set to find the proper number of clusters automatically. Consequently, there were two clusters from these first four variables (inputs) found. The silhouette measure, which is a measure of cohesion and separation of clusters (Figure 1) showed a good result. 
Figure 1 | Silhouette measure of cohesion and separation for FUNCVAL

\section{Cluster Quality}

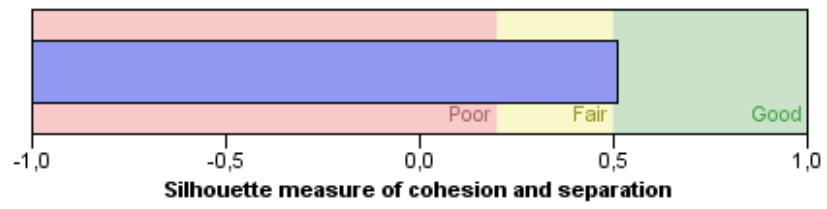

Source: author

From the list of variables which has established cluster membership second item form, the FUNCVAL construct was the most important for the clustering process. Thus, the first cluster comprises 195 respondents for whom the functional value of a fan page is relatively low (average for the cluster is 3.35 on the Likert scale). The second cluster represents all respondents with a significantly more positive attitude towards the fan page of their favourite brand on Facebook. All predictor importance was considerably high (Figure 2).

Figure 2 | Importance of features for cluster formation (FUNCVAL)

\section{Clusters}

Input (Predictor) Importance

$\square 1,0 \square 0,8 \square 0,6 \square 0,4 \square 0,2 \square 0,0$

\begin{tabular}{|c|c|c|}
\hline Cluster & 1 & 2 \\
\hline Losbel & Unjeak & Strong \\
\hline Deseription & $\begin{array}{l}\text { Functional value of } \\
\text { Facebook fan page } \\
\text { for user is low. }\end{array}$ & $\begin{array}{l}\text { Functional value of } \\
\text { Facebook fan page } \\
\text { for user is high }\end{array}$ \\
\hline Size & $\mid$\begin{tabular}{r|r}
43,00 \\
$(195)$
\end{tabular} & $\begin{array}{r}57,0 \% \\
(259)\end{array} \mid$ \\
\hline \multirow[t]{4}{*}{ Inputs } & $\underset{3.35}{\text { FuN }}$ & $\begin{array}{c}\text { FUNCWAL2 } \\
1.95\end{array}$ \\
\hline & $\begin{array}{c}\text { FUNCVAL1 } \\
3,22\end{array}$ & $\begin{array}{c}\text { FUNCVAL1 } \\
1,87\end{array}$ \\
\hline & $\begin{array}{c}\text { FUNCW/AL3 } \\
3,34\end{array}$ & $\begin{array}{c}\text { FUNCVAL3 } \\
1,90\end{array}$ \\
\hline & $\begin{array}{c}\text { FUNCV/AL4 } \\
3,14\end{array}$ & $\begin{array}{c}\text { FUNCVAL4 } \\
1.78\end{array}$ \\
\hline
\end{tabular}

Source: author

The second clustering procedure has been conducted on four HEDONIC item statements. Resulting cluster solution yielded fair silhouette measure of cohesion and separation (Figure 3). Two clusters were identified, and the most significant predictor of the clustering procedure was hedonic item number three (The content of the fan page is entertaining). 
Figure 3 | Silhouette measure of cohesion and separation for HEDONIC

\section{Cluster Quality}

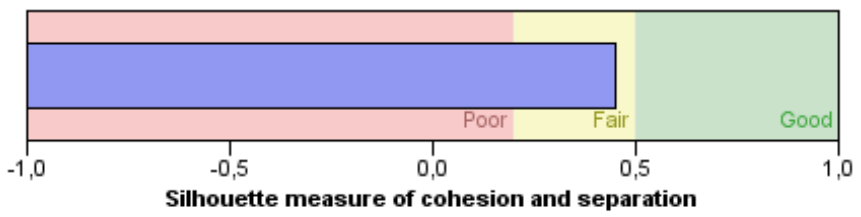

Source: author

Results for clustering the hedonic value are shown in figure 4. The first cluster comprised respondents with a low hedonic value which they get from the brand fan pages on Facebook. There were 260 respondents compared to 194 with high hedonic value. Two questions from the questionnaire (hedonic 2 and 4 ) reached slightly lower predictor importance.

Figure 4 | Importance of features for cluster formation (HEDONIC)

\section{Clusters}

Input (Predictor) Importance

$\square 1,0 \square 0,8 \square 0,6 \square 0,4 \square 0,2 \square 0,0$

\begin{tabular}{|c|c|c|}
\hline Cluster & 1 & 2 \\
\hline Label & vieak & Strong \\
\hline Description & $\begin{array}{c}\text { Hedonic value of } \\
\text { Facebook fan page } \\
\text { for user is low. }\end{array}$ & $\begin{array}{l}\text { Hedonic value of } \\
\text { Facebook fan page } \\
\text { for user is high. }\end{array}$ \\
\hline Size & $\begin{array}{r}57,3 \% \\
(260)\end{array}$ & $\begin{array}{r}42,7 \% \\
(194)\end{array}$ \\
\hline \multirow[t]{4}{*}{ In puts } & $\underset{3.35}{\text { HEDIONICO }}$ & HECIONAIC3 \\
\hline & $\begin{array}{l}\text { HEDONIC1 } \\
4.13\end{array}$ & $\begin{array}{c}\text { HEDONIC1 } \\
2,59\end{array}$ \\
\hline & $\begin{array}{l}\text { HEDONIC2 } \\
3,96\end{array}$ & $\begin{array}{c}\mathrm{HEDONIC2} \\
2,61\end{array}$ \\
\hline & $\begin{array}{c}\text { HEDONIC4 } \\
2,65\end{array}$ & $\begin{array}{l}\text { HEDONIC4 } \\
1,65\end{array}$ \\
\hline
\end{tabular}

Source: author

The three cluster members within the social value variables were distributed as follows. The first cluster comprised a homogenous group of 114 persons for whom the social value of a fan page is high. In the middle, there were 208 respondents who are getting average social value from the fan page. The last cluster was formed by 132 persons with the very low social value from the brand fan page. 
Figure 6 | Importance of features for cluster formation (SOCVAL)

\section{Clusters}

Input (Predictor) Importance

$\square 1,0 \square 0,8 \square 0,6 \square 0,4 \square 0,2 \square 0,0$

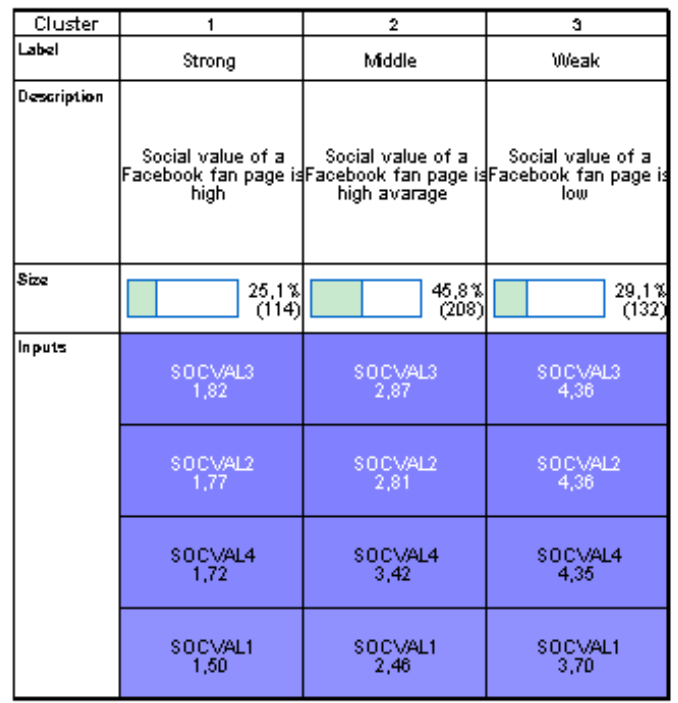

Source: author

Dividing the data set according to these three cluster analysis procedures allows subsequent comparison using the pivot tables. For each of them, the graphical and statistical evaluation will be presented in the following part of the article. Cluster analysis was used once again to process the age variable, which allowed the data set to be split in a more advanced way for younger and older respondents.

\section{Findings and discussion}

Throughout all three clustering procedures, the option to create a new variable with cluster membership was arranged. As a result, there were three new variables in the dataset. These were available for comparison and statistical evaluation. Consequently, the Chi-Square (x2) test of independence in a contingency table was used for evaluating the research question. The first comparison is between function value and gender. In the following figure, we see that the measured values are almost identical (Figure 7). As well as the graphical representation, the chi-square statistics shows that there is no relationship ( $p$-value is higher than 0.05). Differences in data can be considered random. There is no evidence that gender influence perceived the functional value of a fan page. 
Figure 7 | Functional value of the fan page and gender differences

$$
\chi^{2}=0.554 ; p \text {-value }=0.457
$$

High perceived functional value

Low perceived functional value

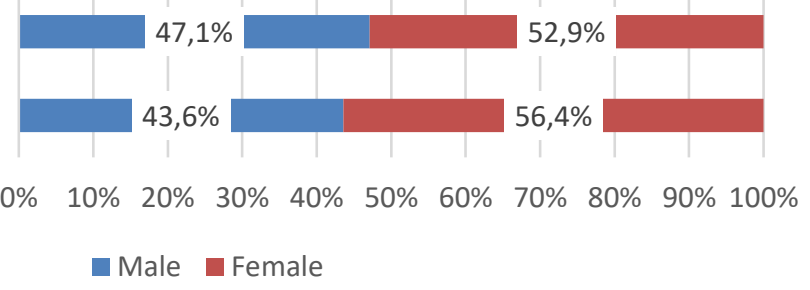

Source: author

The second demographic used for comparison was age. As mentioned before, there was a cluster analysis applied to the age variable, splitting the data set into two parts. First, there were respondents from 18 years of age to 37 (219). The second part of the sample consisted of persons older than 37 years (235). It is possible to see from the following figure that again, age does not relate to any change in responses to functional value construct questions in the survey. Consequently, we have to say that there is no evidence, that age of the respondent influences perceived functional value of the fan pages.

Figure 8 | Functional value of the fan page and age differences

$$
\chi^{2}=0.041 ; p \text {-value }=0.840
$$

High perceived functional value

Low perceived functional value
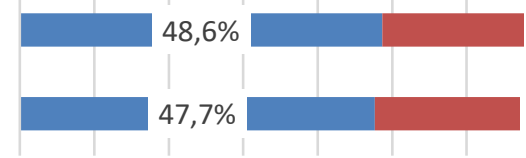

$51,4 \%$

$52,3 \%$

$\begin{array}{llllllllllll}0 \% & 10 \% & 20 \% & 30 \% & 40 \% & 50 \% & 60 \% & 70 \% & 80 \% & 90 \% & 100 \%\end{array}$

- 18 - 37 38+

Source: author

Another value considered in this research was hedonic. Here again, it has been shown that the measurement is not related to the gender of the respondents (Figure 9). Clearly, there is not enough evidence that gender influence perceived the hedonic value of the fan pages. 
Figure 9 | Hedonic value of the fan page and gender differences

$$
\chi^{2}=1.116 ; p \text {-value }=0.291
$$

High perceived hedonic value

Low perceived hedonic value

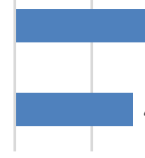

$0 \% \quad 10 \%$

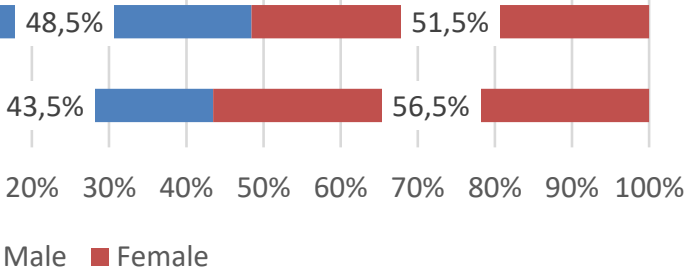

Source: author

The hedonic value was also compared with the age variable. Even though the statistics here is approaching significance, there is still no valid statistical evidence, that age influence perceived the hedonic value of the fan page (Figure 10).

Figure 10 | Hedonic value of the fan page and age differences

$$
\chi^{2}=1.058 ; p \text {-value }=0.304
$$

High perceived hedonic value

Low perceived hedonic value

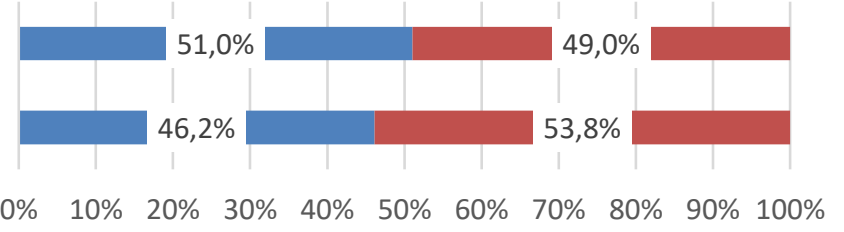

$18-37 \square 38+$

Source: author

Last latent construct used in this study was social value. From the following figure, we can say that slightly more males have higher perceived social value (Figure 11). However, if we submit the data to the statistical test, again, we will come to the same conclusion. There is no enough evidence to say that gender influence perceived the social value of the fan page. 
Figure 11 | Social value of the fan page and gender differences

$$
\chi^{2}=3.866 ; p \text {-value }=0.145
$$

Low perceived social value

Avarage perceived social value

High perceived social value

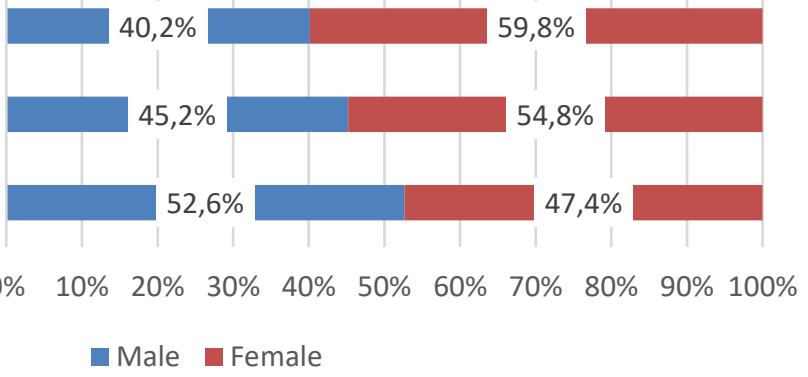

Source: author

In the last figure, social value is compared with age. Similarly, there is not enough evidence that gender influences the perceived social value of the fan page.

Figure 12 | Social value of the fan page and gender differences

$$
\chi^{2}=5.745 ; p \text {-value }=0.057
$$

Low perceived social value

Avarage perceived social value

High perceived social value

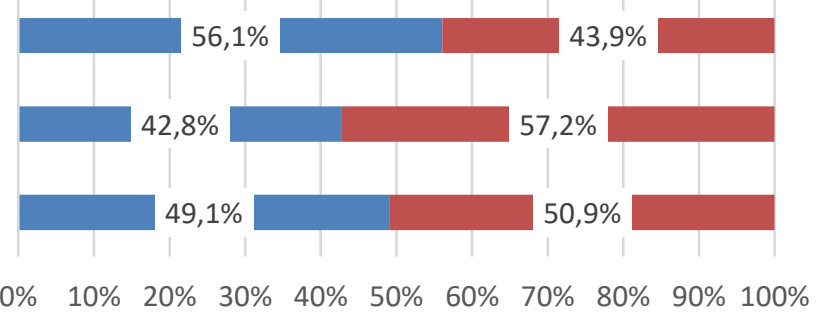

घ 18 - $37 \quad$ a38+

Source: author

\section{Conclusions}

This study has resulted in three different criteria to identify homogenous groups of brand fans on Facebook. All three of them relate to the value which users feel when they follow brands on this social network. As a result, three typologies were developed using cluster analysis and these were then compared with two demographics, and that was gender and age. The age was divided into two using the cluster analysis method. All comparisons were made using pivot tables to see and calculate differences. All relationships were assessed using statistical methods in IBM SPSS software. Chi-square showed that data in all six cases were not statistically significant. Therefore, it can be argued that age and gender are not a determinant of differences in assessing the value the user gets from the branded pages on Facebook. The results go hand in hand with the appeal to use more psychographic for understanding the market. Non-demographic traits such as values, tastes, and preferences are more likely 
to influence consumers' purchases than their demographic traits (Yankelovich \& Meer, 2006). It is becoming obvious that customer behaviour on social media networks is determined mainly by their attitudes and perception, and less by the demographics. The result of this study, therefore, question the usability of demographics-based market segmentation for product development or marketing communication purposes.

On the whole, we now know that the perceived value that the company brings to its Facebook page does not relate to the age or gender of the users. It shows the importance of segmentation based on attitudes and behaviours, and marketers should not rely only on demographic characteristics in social networking environments. The value they provide and the basis on which they should edit the content they share on Facebook exist regardless of these characteristics. Thinking about creating content, for example, for women of a certain age could be dangerous. Marketers should not limit their ideas solely to the demographic characteristics of users. Working with fans on Facebook consists of a detailed understanding of the values that the brand brings and presents there. This research suggests tackling the content creation strategy with three particular values in mind. Whether it is a functional, hedonic or social value, every marketer should realize that the value of a brand fan page for the customers differs. Yet there is no universal rule for communication. One can have a fan base consisted of those who seek hedonic value as well as social value or any other combination of three. Value is the core component of the marketing approach to business. Clearly, clever marketer always thinks about value not only the one embedded in the offering itself but also of the one provided on every media channel in the form of marketing communication.

This study has its limitations which should be described here since these fuel interest in further research. The first domain of limitations is connected with the sample, which was selected from Czech Facebook users addressed by the professional research company. Further studies could incorporate a broader sample or use other countries and then compare results with the presented data. Moreover, the people surveyed were participants in the marketing research agency database. Even thou we screened data for straight-lining, in some cases, these types of respondents could have developed ways how to provide inaccurate answers without being noticed by control mechanisms. The second domain of limitations concerns the reliability of the data. The questionnaire was designed to measure perceived values, which could be highly subjective and develop over time. Studies using behavioural data straight from Facebook could help to bridge the gap between what consumers think or feel and how they actually behave. Moreover, we assume the product category could be a significant factor affecting the expected value from the brand communication on Facebook and studies sampling only particular brand fans could focus on measuring hedonic, utilitarian and social value exclusively for one fan page.

\section{Acknowledgement}

This research was financially supported by the Internal grant competition project IGS/11/18: "Consumer typology from the point of view of motivation to interact with brands on social networks."

\section{References}

Bachmann, P., Kantorová K. (2016). From Customer Orientation to Social CRM. New Insights from Central Europe. Scientific Papers of the University of Pardubice, 36 (23), 29-41. 
Barber, N. (2009). Wine consumers information search: Gender differences and implications for the hospitality industry. Tourism and Hospitality Research, 9(3), 250-269.

Blunch, N. (2013). Introduction to Structural Equation Modeling Using IBM SPSS Statistics and Amos (2 edition). Los Angeles: Sage Publications Ltd.

Boyd, D. M., \& Ellison, N. B. (2007). Social Network Sites: Definition, History, and Scholarship. Journal of Computer-Mediated Communication, 13(1), 210-230. https://doi.org/10.1111/j.10836101.2007.00393.x

Brettel, M., Reich, J.-C., Gavilanes, J. M., \& Flatten, T. C. (2015). What Drives Advertising Success on Facebook? An Advertising-Effectiveness Model: Measuring the Effects on Sales Of "Likes" and Other Social-Network Stimuli. Journal of Advertising Research, 55(2), 162-175. https://doi.org/10.2501/JAR-55-2-162-175

Brodie, R. J., Hollebeek, L. D., Jurić, B., \& llić, A. (2011). Customer Engagement: Conceptual Domain, Fundamental Propositions, and Implications for Research. Journal of Service Research, 14(3), 252-271. https://doi.org/10.1177/1094670511411703

Brooks, L., \& Anene, V. (2012). Information Disclosure and Generational Differences in Social Network Sites. Retrieved December 18, 2019, from https://aisel.aisnet.org/amcis2012/proceedings/Sociallssues/10

Carlson, J., Rahman, M., Voola, R., \& De Vries, N. (2018). Customer engagement behaviours in social media: Capturing innovation opportunities. Journal of Services Marketing, 32(1), 83-94. https://doi.org/10.1108/JSM-02-2017-0059

Clement, J. (2019). Distribution of Facebook users worldwide as of October 2019, by age and gender. Retrieved December 11, 2019, from https://www.statista.com/statistics/376128/facebook-globaluser-age-distribution/

Coley, A., \& Burgess, B. (2003). Gender differences in cognitive and affective impulse buying. Journal of Fashion Marketing and Management: An International Journal, 7(3), 282-295. https://doi.org/10.1108/13612020310484834

Cvijikj, I. P., \& Michahelles, F. (2013). Online engagement factors on Facebook brand pages. Social Network Analysis and Mining, 3(4), 843-861. https://doi.org/10.1007/s13278-013-0098-8

Daugherty, T., Eastin, M. S., \& Bright, L. (2008). Exploring consumer motivations for creating usergenerated content. Journal of Interactive Advertising, 8(2), 16-25.

Davies, R. S. (2011). Understanding Technology Literacy: A Framework for Evaluating Educational Technology Integration. TechTrends, 55(5), 45-52. https://doi.org/10.1007/s11528-011-0527-3

De Vries, L., Gensler, S., \& Leeflang, P. S. H. (2012). Popularity of Brand Posts on Brand Fan Pages: An Investigation of the Effects of Social Media Marketing. Journal of Interactive Marketing, 26(2), 83-91. https://doi.org/10.1016/j.intmar.2012.01.003

De Vries, N. J., \& Carlson, J. (2014). Examining the drivers and brand performance implications of customer engagement with brands in the social media environment. Journal of Brand Management, 21(6), 495-515. https://doi.org/10.1057/bm.2014.18

Dessart, L., Veloutsou, C., \& Morgan-Thomas, A. (2015). Consumer engagement in online brand communities: A social media perspective. Journal of Product \& Brand Management, 24(1), 2842. https://doi.org/10.1108/JPBM-06-2014-0635

Dijkmans, C., Kerkhof, P., \& Beukeboom, C. J. (2015). A stage to engage: Social media use and corporate reputation. Tourism Management, 47, 58-67. https://doi.org/10.1016/j.tourman.2014.09.005 
Van Doorn, J., Lemon, K. N., Mittal, V., Nass, S., Pick, D., Pirner, P., \& Verhoef, P. C. (2010). Customer Engagement Behavior: Theoretical Foundations and Research Directions. Journal of Service Research, 13(3), 253-266. https://doi.org/10.1177/1094670510375599

Duffett, R. G. (2017). Influence of social media marketing communications on young consumers' attitudes. Young Consumers, 18(1), 19-39. https://doi.org/10.1108/YC-07-2016-00622

Duncan, T., \& Moriarty, S. E. (1998). A Communication-Based Marketing Model for Managing Relationships. Journal of Marketing, 62(2), 1-13. https://doi.org/10.2307/1252157

Flórez, L.E.G., Escobar, M.I.C., Restrepo, A.H., Arango-Botero, D., \& Valencia-Arias, A. (2018). Influence of social networks on the purchase decisions of university students. Cuadernos de Gestión, 18(3), 61-84.

Greve, G. (2014). The Moderating Effect of Customer Engagement on the Brand Image - Brand Loyalty Relationship. Procedia - Social and Behavioral Sciences, 148, 203-210. https://doi.org/10.1016/j.sbspro.2014.07.035

Hair, J., Hult, G. T. M., Ringle, C. M., \& Sarstedt, M. (2017). A Primer on Partial Least Squares Structural Equation Modeling (2nd edition). Los Angeles: SAGE Publications, Inc.

Hennig-Thurau, T., Malthouse, E. C., Friege, C., Gensler, S., Lobschat, L., Rangaswamy, A., \& Skiera, B. (2010). The Impact of New Media on Customer Relationships. Journal of Service Research, 13(3), 311-330. https://doi.org/10.1177/1094670510375460

Hoffman, D. L., \& Novak, T. P. (1996). Marketing in Hypermedia Computer-Mediated Environments: Conceptual Foundations. Journal of Marketing, 60(3), 50-68. https://doi.org/10.2307/1251841

Hoffman, D.L., Novak, T.P., \& Stein, R. (2012). The Digital Consumer. In Belk, R.W., \& Llamas, R. (Eds.), The Routledge Companion to Digital Consumption (pp. 28-38). London: Routledge.

Hutchinson, A. (2019). Facebook Reaches 2.38 Billion Users, Beats Revenue Estimates in Latest Update. Retrieved November 16, 2019, from https://www.socialmediatoday.com/news/facebookreaches-238-billion-users-beats-revenue-estimates-in-latest-upda/553403/

Hutter, K., Hautz, J., Dennhardt, S., \& Füller, J. (2013). The impact of user interactions in social media on brand awareness and purchase intention: The case of MINI on Facebook. Journal of Product \& Brand Management, 22(5/6), 342-351. https://doi.org/10.1108/JPBM-05-2013-0299

Jahn, B., \& Kunz, W. (2012). How to transform consumers into fans of your brand. Journal of Service Management, 23(3), 344-361. https://doi.org/10.1108/09564231211248444

Kaplan, A. M., \& Haenlein, M. (2010). Users of the world, unite! The challenges and opportunities of Social Media. Business Horizons, 53(1), 59-68. https://doi.org/10.1016/j.bushor.2009.09.003

Karlíček, M., Tomek, I., Hasprová, M., \& Zamazalová, M. (2012). Social Networking Sites in the Czech Republic: An Empirical Study. Management \& Marketing, 7(1), 15-28.

Kiani, G. R. (1998). Marketing opportunities in the digital world. Internet Research-Electronic Networking Applications and Policy, 8(2), 185-194. https://doi.org/10.1108/10662249810211656

Killian, G., \& McManus, K. (2015). A marketing communications approach for the digital era: Managerial guidelines for social media integration. Business Horizons, 58(5), 539-549. https://doi.org/10.1016/j.bushor.2015.05.006

Kim, Y., Dykema, J., Stevenson, J., Black, P., \& Moberg, D. P. (2019). Straightlining: Overview of Measurement, Comparison of Indicators, and Effects in Mail-Web Mixed-Mode Surveys. Social Science Computer Review, 37(2), 214-233. https://doi.org/10.1177/0894439317752406 
Kimbrough, A. M., Guadagno, R. E., Muscanell, N. L., \& Dill, J. (2013). Gender differences in mediated communication: Women connect more than do men. Computers in Human Behavior, 29(3), 896900. https://doi.org/10.1016/j.chb.2012.12.005

Larivière, B., Joosten, H., Malthouse, E. C., Birgelen, M. V., Aksoy, P., Kunz, W. H., \& Huang, M. (2013). Value fusion: The blending of consumer and firm value in the distinct context of mobile technologies and social media. Journal of Service Management, 24(3), 268-293. https://doi.org/10.1108/09564231311326996

Lee, M. R., Yen, D. C., \& Hsiao, C. Y. (2014). Understanding the perceived community value of Facebook users. Computers in Human Behavior, 35, 350-358. https://doi.org/10.1016/j.chb.2014.03.018

Lin, K.-Y., \& Lu, H.-P. (2011). Why people use social networking sites: An empirical study integrating network externalities and motivation theory. Computers in Human Behavior, 27(3), 1152-1161. https://doi.org/10.1016/j.chb.2010.12.009

Llamas, R., \& Belk, R.W. (2012). Living in a Digital World. In Belk, R.W., \& Llamas, R., (Eds.), The Routledge Companion to Digital Consumption (pp. 3-12). London: Routledge.

Logan, K. (2014). Why Isn't Everyone Doing It? A Comparison of Antecedents to Following Brands on Twitter and Facebook. Journal of Interactive Advertising, 14(2), 60-72. https://doi.org/10.1080/15252019.2014.935536

Muntinga, D. G., Moorman, M., \& Smit, E. G. (2011). Introducing COBRAs. International Journal of Advertising, 30(1), 13-46. https://doi.org/10.2501//JA-30-1-013-046

Novotná, J. (2018). Exploring Customer Loyalty to Fashion Brands on Facebook Fan Pages. E+M Ekonomie a Management, 21(1), 206-223. https://dx.doi.org/10.15240/tul/001/2018-1-014

Ozuem, W., Howell, K. E., \& Lancaster, G. (2008). Communicating in the new interactive marketspace. European Journal of Marketing, 42(9-10), 1059-1083. https://doi.org/10.1108/03090560810891145

Pereira, H. G., de Fátima Salgueiro, M., \& Mateus, I. (2014). Say yes to Facebook and get your customers involved! Relationships in a world of social networks. Business Horizons, 57(6), 695702. https://doi.org/10.1016/j.bushor.2014.07.001

Raacke, J., \& Bonds-Raacke, J. (2008). MySpace and Facebook: Applying the uses and gratifications theory to exploring friend-networking sites. Cyberpsychology \& Behavior: The Impact of the Internet, Multimedia and Virtual Reality on Behavior and Society, 11(2), 169-174. https://doi.org/10.1089/cpb.2007.0056

Sabate, F., Berbegal-Mirabent, J., Cañabate, A., \& Lebherz, P. R. (2014). Factors influencing popularity of branded content in Facebook fan pages. European Management Journal, 32(6), 1001-1011. https://doi.org/10.1016/j.emj.2014.05.001

Saunders, M., Lewis, P., \& Thornhill, A. (2009). Research Methods for Business Students (5th edition). Harlow: Pearson Education.

Schivinski, B., \& Dabrowski, D. (2015). The impact of brand communication on brand equity through Facebook. Journal of Research in Interactive Marketing, 9(1), 31-53. https://doi.org/10.1108/JRIM-02-2014-0007

Schivinski, B., \& Dabrowski, D. (2016). The effect of social media communication on consumer perceptions of brands. Journal of Marketing Communications, 22(2), 189-214. https://doi.org/10.1080/13527266.2013.871323

Sheldon, P. (2008). Students Favorite: Facebook and Motives for its Use. Southwestern Mass Communication Journal, 23(2), 39-53. 
So, K. K. F., King, C., \& Sparks, B. (2012). Customer Engagement With Tourism Brands: Scale Development and Validation. Journal of Hospitality \& Tourism Research, 38(3), 304-329. https://doi.org/10.1177/1096348012451456

SPIR (2019). Výsledky NetMonitor a AdMonitoring za záři 2019. Retrieved February 16, 2020, from https://www.spir.cz/sites/default/files/prilohy/SPIR_2019_10_kvartalni_prezentace_zkracena.pd $f$

Tifferet, S., \& Herstein, R. (2012). Gender differences in brand commitment, impulse buying, and hedonic consumption. Journal of Product \& Brand Management, 21(3), 176-182. https://doi.org/10.1108/10610421211228793

Tomek, I., Hasprová, M., Zamazalova, M., \& Karlíček, M. (2012). Behaviour of the Czech internet heavy users in online social media environment. Intellectual economics, 6(2), 189-196.

Van der Heijden, H. (2004). User Acceptance of Hedonic Information Systems. MIS Quarterly, 28(4), 695-704. https://doi.org/10.2307/25148660

Wang, J.-C., \& Chang, C.-H. (2013). How online social ties and product-related risks influence purchase intentions: A Facebook experiment. Electronic Commerce Research and Applications, 12(5), 337-346. https://doi.org/10.1016/j.elerap.2013.03.003

Yang, K., \& Lee, H. (2010). Gender differences in using mobile data services: Utilitarian and hedonic value approaches. Journal of Research in Interactive Marketing, 4(2), 142-156. https://doi.org/10.1108/17505931011051678

Yankelovich, D., \& Meer, D. (2006). Rediscovering Market Segmentation, Retrieved November 14, 2019, from https://hbr.org/2006/02/rediscovering-market-segmentation

The research paper passed the review process. | Received: December 30, 2019; Revised: February 20, 2020; Accepted: March 21, 2020; Published: July 10, 2020. 